\title{
The Associations of Serum AMH, Vitamin D, FSH and AFC in Different Age Groups of Infertile Women
}

\author{
Hiba H. Kadhim* and Salman A. Ahmed \\ Department of Chemistry, College of Science, Al-Nahrain University, Baghdad, Iraq \\ *Corresponding author:
}

\section{Keywords}

Anti-Mullerian

Hormone, Follicle stimulating

hormone, Mullerian inhibiting substance, Vitamin D

\section{Article Info}

Accepted: 10 December 2018 Available Online: 10 January 2019

\section{A B S T R A C T}

The objective of our study was to identify the associations between the tests that used in ovarian reserve assessment: Anti-Mullerian hormone (AMH), follicle stimulating hormone (FSH) and antral follicle count (AFC) and to distinguish the most reliable markers for ovarian reserve in order to select an adequate strategy for the initial stages of infertility treatment and identify the effect of vitamin $\mathrm{D}$ on the ovarian reserve and its correlation with AMH. Anti-mullerian hormone (AMH) is expressed only in the gonads. In female it's secreted by adult granulosa cells of the ovary. The levels of AMH reflect the number of preantral follicles and thus as a marker of oocyte pool which is a germinal reserve of the ovary for reproduction. Vitamin D is a fat-soluble vitamin that belongs to the family of steroid hormones. It has a biologically plausible role in female reproduction. In this paper AMH, FSH and Vitamin D was determined by enzyme linked immunosorbent assay in: 60 infertile women with PCOS (cases) undergoing IVF and 30 healthy women had one child at least (control). The antral follicle count (AFC) was recorded for each female in case group. The AMH and 25(OH) D levels in cases were lower than that of control, while FSH level in cases was higher than control group. The AMH in cases was significantly decreased with increasing age. The AFC was inversely associated with age. There was a significant positive association between ovarian response in terms of the antral follicle count and AMH levels, there was no association between ovarian response in terms of the AFC with 25(OH)D and FSH implying that AMH can be used as a good predictor of ovarian reserve and ovarian response. The correlation between $25(\mathrm{OH}) \mathrm{D}$ and $\mathrm{AMH}$ among women ages 36-42 showed that AMH levels decreased significantly with increasing 25(OH)D levels, and was found no statistically significant correlation between 25(OH)D and AMH among women under the age of 36 .

\section{Introduction}

AMH is an important member of the TGF-b super family secreted by granular cells (GCs) and plays an important role in the folliculogenesis. It has the highest expression in small antral follicles and major suppresses primordial follicles into the growth phase (Goodarzi et al., 2011). Infertility is a complex issue with significant medical, psychosocial, and economic problems. Polycystic ovarian syndrome (PCOS) is one of the most common endocrine disorders (Norman et al., 2007), affecting up to 5 to $10 \%$ reproductive-aged 
women (Qiao et al., 2013) and is one of the most major cause of infertility. The major clinical features of PCOS contain the four common symptoms: menstrual disorders, Infertility hyperandrogenemia, and metabolic syndrome- (Trikudanathan et al., 2015). FSH in females, initiates follicular growth, specifically affecting GCs. It is thought that each follicle has its own threshold FSH concentration varying from hypo-response to a risk of ovarian hyperstimulation and this concentration has to be exceeded to ensure dominant follicle selection. It is reported that AMH inhibits FSH-stimulated follicle growth (Durlinger et al., 2001) and is one of the factors restrains the sensitivity of ovarian follicles for $\mathrm{FSH}$, thus preventing follicle selection and resulting in follicle arrest at the small antral phase, with failure of dominance (Grossman et al., 2008). It is suggested the GCs from polycystic ovaries continue to produce elevated levels of AMH, possibly because of impaired access of FSH to follicles (Desforges-Bullet et al., 2010). AMH seems to be involved in the inhibition of FSH action by repressing the FSH-dependent aromatase activity. So in anovulatory patients, although the serum FSH is at low/normal concentrations, AMH level is not low sufficient to allow the expression of aromatase (Catteau-Jonard et al., 2013).

\section{Vitamin D}

It is an essential steroid hormone classically known for its role in maintenance of calcium and phosphatehomeostasis. Vitamin D is largely generated in the epidermis with exposure to ultraviolet radiation. Two different forms of vitamin $\mathrm{D}$ from dietary sources are vitamin $\mathrm{D}_{2}$ (ergocalciferol) derived from plants and vitamin $D_{3}$ (cholecalciferol) derived from animals (Bouillon et al., 2015). The cutaneous precursor of vitamin $\mathrm{D}$, previtamin $\mathrm{D}_{3}$ (7dehydrocholesterol), is derived from cholesterol in food. After exposure to short wave UVB radiation the $B$ ring of 7dehydrocholesterol is transformed into previtamin $\mathrm{D}_{3}$ (cholecalciferol) or converted into two inactive products. It undergoes two hydroxylation steps by $\mathrm{P} 450$ mixed function mono-oxidases. In the liver, vitamin D hydroxylation into 25-hydroxyvitamin D $(25(\mathrm{OH}) \mathrm{D})$ is modulated by the mitochondrial CYP27A1 or the microsomal CYP2R1.Further hydroxylation takes place in the kidney in the proximal convoluted tubule to the physiologically active form, $1 \quad \alpha, 25$ dihydroxyvitamin D3 (1,25(OH)2D3),by CYP27B1.

Active vitamin D binds to VDBP and is transported to target cells. Once the complex reaches the target cell, vitamin $\mathrm{D}$ is released from the VDBP and $1,25(\mathrm{OH})_{2} \mathrm{D}_{3}$ binds to vitamin $\mathrm{D}$ receptors (VDR) present in the cytoplasm. VDR transports vitamin D into the nucleus. The female reproductive system, as the male reproductive system, is composed of central regulators including the hypothalamus and the pituitary gland and peripheral organs such as the ovary, uterus, and during pregnancy the placenta. In vitro studies have shown a direct modulation by vitamin $\mathrm{D}$ of estradiol, estrone, and progesterone production in human ovarian cells (Parikh et al., 2010) in female reproductive physiology. AntiMullerian hormone (AMH) is a marker of ovarian reserve.

There have been several studies suggesting modulation of AMH levels by vitamin D. A functional VDRE has been noted in the promoter region of the AMH gene (Molly et al., 2009).

Association studies in humans have shown a positive correlation between vitamin $\mathrm{D}$ and AMH levels. One study in women with regular menstrual cycles has shown decreased AMH levels with lower vitamin D levels (Merhi et al., 2014). 


\section{Materials and Methods}

The present study comprised of 60 infertile women with symptoms of PCOS undergoing IVF and 30 healthy women. The studied population was divided into three subgroups according to their age: $\leq 25,26-36$ and $>36$ years. Blood samples were collected from individual on 2-3 days of their spontaneous menstrual cycles the numbers of antral follicles that measured $2-10 \mathrm{~mm}$ in size were counted in each ovary. The sum of both counts was the AFC.

Samples were hospitalized at laboratories in the Al-Zahraa Al-Batool private hospital. the samples were collected from October 2017 to February 2018,blood samples were collected $(5 \mathrm{ml})$ and centrifuged at [4000 rpm] for 10 min after clotting, to separate the serum from the cells to determine human serum AMH, FSH and Vitamin D levels. The resultant serum was separated and stored at $[-20]{ }^{\circ} \mathrm{C}$ until time of analyses.

Human serum Anti-Mullerian Hormone $(\mathrm{AMH})$, Follicle Stimulating Hormone (FSH) and Vitamin $\mathrm{D}$ were measured by using (ELISA) an enzyme-linked- immune-sorbent assay kit (Sandwich) technologies for individual using commercially available kits AMH, FSH and 25-OHvitaminD (YHLO Biotech, South Korea).

\section{Statistical analysis}

Statistical analysis of data, was performed using Mini-Tab-System version 18.1). Oneway ANOVA test was used for analysis of variance for average hormone level as quantitative variable by qualitative variable. Correlation coefficient (r) between vitamin D and AMH was used. The results in all the above mentioned procedures were accepted as statistically significant when the p-value was less than $5 \%(\mathrm{p}<0.05)$.

\section{Results and Discussion}

The mean levels of AMH, FSH, and 25(OH)D recorded in the present study for cases were more or less close to other study (Ficicioglu et al., 2006) When compared to controls AMH and 25OH-D where significantly lower than those encountered in the controls $(3.738 \pm 2.279$ vs. $2.568 \pm 1.960 \mathrm{ng} / \mathrm{mL}$ and $31.77 \pm 7.48 \quad$ vs. $\quad 10.511 \pm 3.041 \mathrm{pg} / \mathrm{ml}$, respectively).

FSH was significantly higher in cases than controls. Consequently, the lower level of AMH observed in most women with PCOS undergoing IVF. Although FSH levels in the cases were higher than those of controls, they are still within the normal range of 3-11 $\mathrm{mIU} / \mathrm{ml}$ (Tietz et al., 1995) indicating that FSH alone is not sufficient to predict the female reproductive potential (Grossman et al., 2008) and support the hypothesis that there is a reverse relationship between AMH and FSH. Statistical data suggested that among infertile women there is a high incidence of Vitamin D deficiency.) A study found that $90.8 \%$ of women being worked up for infertility had insufficient $(68.6 \%)$ or deficient $(22.2 \%)$ vitamin D levels (Schriock et al., 2012). Likewise, another study by (Anifandis et al., 2010) from Greece reported $79 \%$ of women undergoing in vitro fertilization (IVF) were vitamin D insufficient or deficient.

Our study reports $66.6 \%$ of infertile women having vitamin $\mathrm{D}$ deficiency. There is some evidence that vitamin $\mathrm{D}$ deficiency and its effects on fertility may be indirect. Without vitamin $\mathrm{D}$, the body absorbs up to $30 \%$ less calcium and $20 \%$ less phosphorus. In experimental conditions, when the hypocalcaemia and hypophosphatemia were corrected in the female their fertility returned (Johnson et al., 2010). It's possible the primary cause of infertility may be 
hypocalcaemia-and/or hypophosphatemia. We examined the relationships between age and ovarian reserve indicators in the case group. Age showed a significant negative association with AMH level $(\mathrm{F}=5.2, \mathrm{p}<0.008)$ and $\mathrm{AFC}$ $(\mathrm{F}=3.61, \mathrm{p}<0.03)$ and significant positive association with $25(\mathrm{OH}) \mathrm{D}$. There was no association between age and $\mathrm{FSH}(\mathrm{F}=0.630$, $\mathrm{p}=0.538)$. AMH showed a positive correlation with $\operatorname{AFC}(F=7.31, p<0.0001)$. There was no association between AFC with vitamin D $(\mathrm{F}=1.06, \mathrm{p}<0.375)($ Fig. $1-3$ and Table 1).
The relationship between AMH, FSH, AFC and vitamin $D$ levels and age

The mean levels of AMH in relation to the age of the study population are illustrated in Table 2 . According to their age, the study population was divided into three groups: $\leq 25,26-36$ and $>36$ years. The mean levels of AMH in cases was significantly decreased with increasing age $(3.656 \pm 2.675 \mathrm{ng} / \mathrm{mL}, \quad 2.175 \quad \pm 1.249$ $\mathrm{ng} / \mathrm{mL}$ and $1.536 \pm 1.376 \mathrm{ng} / \mathrm{mL}$ at $\leq 25,26-36$ and $>36$ years, respectively; $\mathrm{F}=5.20$ and $\mathrm{p}=0.008)($ Table 2).

Table.1 The mean levels of AMH, FSH and vitamin D in cases as compared to controls

\begin{tabular}{|c|c|c|c|}
\hline Parameters & $\begin{array}{c}\text { Case } \\
(\mathbf{N}=60)\end{array}$ & $\begin{array}{c}\text { Control } \\
(\mathbf{N}=\mathbf{3 0})\end{array}$ & p-value \\
\hline $\begin{array}{c}\text { AMH } \\
(\mathbf{n g} / \mathbf{m L})\end{array}$ & $2.568 \pm 1.960$ & $3.738 \pm 2.279$ & $0.023^{*}$ \\
\hline $\begin{array}{c}\mathbf{F S H} \\
(\mathbf{m I U} / \mathbf{m L})\end{array}$ & $8.026 \pm 3.084$ & $6.63 \pm 2.467$ & $0.034^{*}$ \\
\hline $\begin{array}{c}\mathbf{2 5}(\mathbf{O H}) \mathbf{D} \\
(\mathbf{n g} / \mathbf{m L})\end{array}$ & $10.511 \pm 3.041$ & $31.77 \pm 7.48$ & $0000^{*}$ \\
\hline
\end{tabular}

Note: Values are represented with means and $\pm \mathrm{SD}$; $\mathrm{p}^{*}$; significant MH; Anti-Mullerian Hormone; FSH: Follicle Stimulating Hormone; 25(OH)D: 25-hydroxyvitamin D

Table. 2 The relationship between AMH, FSH and vitamin D levels and age

\begin{tabular}{|c|c|c|c|c|c|}
\hline AGE (year) & $\leq \mathbf{2 5}$ & $26-36$ & $>36$ & $\mathbf{F}$ & P-value \\
\hline $\begin{array}{c}\text { AMH } \\
(\mathbf{n g} / \mathbf{m L})\end{array}$ & $\begin{array}{c}3.656 \\
\pm \\
2.675\end{array}$ & $\begin{array}{c}2.175 \\
\pm \\
1.249\end{array}$ & $\begin{array}{c}1.356 \\
\pm \\
1.376\end{array}$ & 5.20 & $0.008 *$ \\
\hline $\begin{array}{c}\text { FSH } \\
(\mathbf{m I U} / \mathbf{m L})\end{array}$ & $\begin{array}{c}7.778 \\
\pm \\
2.892\end{array}$ & $\begin{array}{c}8.006 \\
\pm \\
3.132\end{array}$ & $\begin{array}{c}7.383 \\
\pm \\
3.493\end{array}$ & 0.630 & 0.538 \\
\hline AFC & $\begin{array}{c}19.21 \\
\pm \\
6.70\end{array}$ & $\begin{array}{c}14.71 \\
\pm \\
6.06\end{array}$ & $\begin{array}{c}13.00 \\
\pm \\
8.83\end{array}$ & 3.61 & $0.033^{*}$ \\
\hline $\begin{array}{c}25(\mathrm{OH}) \mathrm{D} \\
(\mathrm{ng} / \mathrm{mL})\end{array}$ & $\begin{array}{c}9.02 \\
\pm \\
2.539\end{array}$ & $\begin{array}{c}11.116 \\
\pm \\
3.189\end{array}$ & $\begin{array}{c}11.556 \\
\pm \\
2.338\end{array}$ & 3.60 & $0.034 *$ \\
\hline
\end{tabular}

Note: Values are represented with means and \pm SD; p; $^{*}$ significant; AMH; Anti-mullerian Hormone; FSH: Follicle Stimulating Hormone; 25(OH)D: 25-hydroxyvitamin D, AFC: antral follicle count 
Table.3 The correlation between the vitamin D and AMH

\begin{tabular}{|c|c|c|c|c|c|}
\hline $\begin{array}{c}\text { Serum } \\
\mathbf{2 5}(\mathbf{O H}) \mathbf{D} \\
(\mathbf{n g} / \mathbf{m l})\end{array}$ & Age & $\begin{array}{c}<\mathbf{1 0} \\
\mathbf{n g} / \mathbf{m l}\end{array}$ & $\begin{array}{c}\mathbf{1 1 - 2 0} \\
\mathbf{n g} / \mathbf{m l}\end{array}$ & $\begin{array}{c}\mathbf{2 1 - 8 0} \\
\mathbf{n g} / \mathbf{m l}\end{array}$ & $\mathbf{P}$ \\
\hline $\begin{array}{c}\mathbf{A M H} \\
(\mathbf{n g} / \mathbf{m L})\end{array}$ & $20-36$ & $2.887 \pm 1.930$ & $2.305 \pm 2.025$ & $3.738 \pm 2.279$ & 0.859 \\
\hline $\begin{array}{c}\text { Serum } \\
\mathbf{2 5}(\mathbf{O H}) \mathbf{D} \\
(\mathbf{n g} / \mathbf{m l})\end{array}$ & Age & $\begin{array}{c}<10 \\
\mathrm{ng} / \mathrm{ml}\end{array}$ & $\begin{array}{c}11-20 \\
\mathrm{ng} / \mathrm{ml}\end{array}$ & $\begin{array}{c}21-80 \\
\mathrm{ng} / \mathrm{ml}\end{array}$ & $\mathrm{P}$ \\
\hline $\begin{array}{c}\mathbf{A M H} \\
(\mathbf{n g} / \mathbf{m L})\end{array}$ & $36-42$ & $1.077 \pm 0.665$ & $1.880 \pm 1.767$ & $6.47 \pm 6.44$ & $0.006^{*}$ \\
\hline
\end{tabular}

Note: Values are represented with means and $\pm \mathrm{SD} ; \mathrm{p}^{*}$; significant

Fig.1 The chemical structure of vitamin $\mathrm{D}_{2}$ and $\mathrm{D}_{3}$

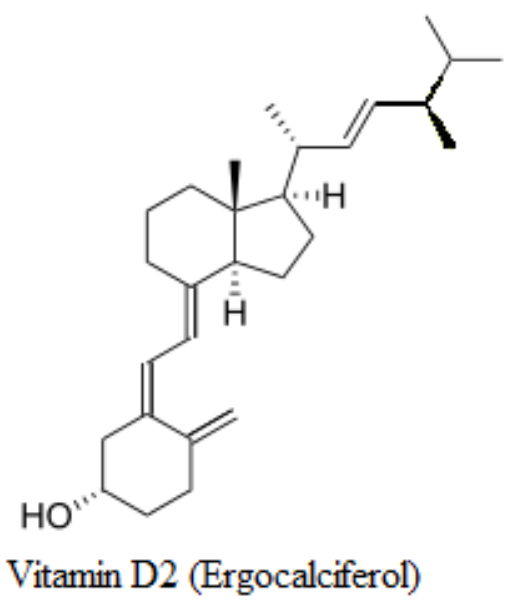

Fig.2 The chemical structure of 25-hydroxy vitamin $\mathrm{D}_{3}$<smiles>C=C1CC[C@H](O)C/C1=C/C=C1\CCCC2(C)C1CC[C@H]2[C@H](C)CCCC(C)(C)O</smiles> 
Fig.3 The chemical structure of 1,25-hydroxy vitamin $D_{3}$

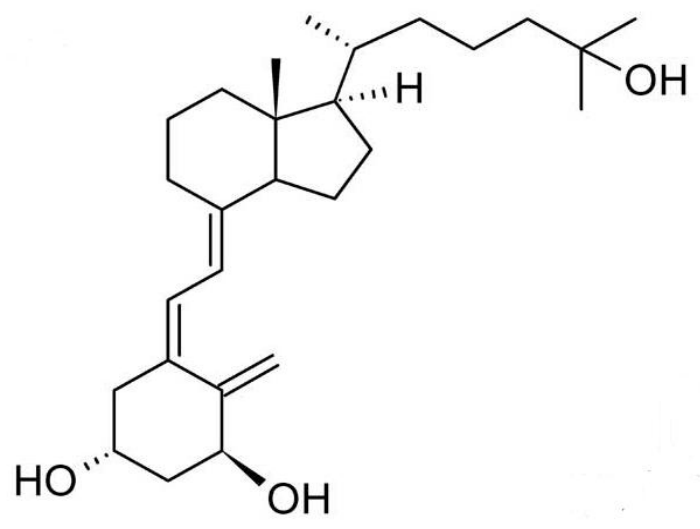

The mean levels of AMH, FSH, and vitamin $\mathrm{D}$ recorded in the present study for cases were more or less close to those reported by another study (Qiao et al., 2013). Table 2 lists the differences between groups for the mean \pm standard deviation AMH, FSH, 25(OH)D and AFC values. There were significantly higher AMH levels in group I compared with groups II and III. This value was also higher in group II compared to group III. The antral follicle count

(AFC) were significantly higher in group I compared with group III, FSH and 25(OH)D levels were significantly higher only in group II compared to group I. Data presented in this study showed that the mean levels of AMH in cases decreased with increasing age. This inverse relationship is in agreement with that found by another study (Van Rooij et al., 2005) which is reported that serum AMH levels decline with age in women with proven fertility. They added that serum AMH represents the best endocrine marker with their age groups (the young, the adult and the elderly group) was investigated. In this study, the relationship between the serum vitamin $\mathrm{D}$ level of patient with their age groups (the young, the adult and the elderly group) was investigated. And its showed a significant relationship of vitamin $\mathrm{D}$ with age of cases $(\mathrm{P}=0.03)$. In line with our study, another study found serum 25 dihydroxy-vitamin D levels in the older age groups were higher when compared with the adults (Steingrimsdottir et al., 2005). Likewise, a significant relationship of serum vitamin $\mathrm{D}$ levels with age of the patient was detected too by (Baradaran A et al., 2012). Accordingly, with another study found a positive relationship between serum 25(OH)D levels and age of patient (Bischoff-Ferrari et al., 2004).

\section{The correlation between the vitamin $\mathrm{D}$ and AMH}

The present study found that $66.6 \%$ of the study population was suffering from either vitamin $\mathrm{D}$ insufficiency or deficiency according to Holick's classification (Holick et al., 2007) and decreased serum AMH level was associated with vitamin D deficiency. Although previous studies have investigated serum 25(OH)D concentrations in infertile women by age group (Merhi et al., 2014) and they observed that vitamin D treatment downregulated AMH receptor (AMHR) gene expression and signaling by interruption of Smad 1/5/8 phosphorylation and its nuclear translocation., an inverse correlation existed 
between follicular fluid 25(OH)D levels and AMH receptor-II (AMHR-II) mRNA gene expression. Women with insufficient/deficient levels of $25(\mathrm{OH}) \mathrm{D}$ in follicular fluid displayed a 2-fold increase in AMHR-II mRNA expression levels compared to those with sufficient $25(\mathrm{OH}) \mathrm{D}$ levels. At the serum level, (Merhi et al., 2014) levels observed a weak negative association between vitamin $\mathrm{D}$ and AMH among women under 35 years of age and a weak positive relationship above 40 years of age. Another study suggested that vitamin D may influence the ovarian reserve. A study of group of women found that women $<30$ years old had significantly lower mean serum 25(OH)D levels compared with women $\geq 30$ years old, and $42.1 \%$ of these younger women were vitamin D-deficient (Nakamura et al., 2014). In the present study showed an AMH levels decreased significantly with increasing $25(\mathrm{OH}) \mathrm{D}$ levels among women ages 36-42, and found no statistically significant correlation between $25(\mathrm{OH}) \mathrm{D}$ and $\mathrm{AMH}$ among women under the age of 36 (Ross et al., 2014) (Table 3).

In conclusion, through our research, we found that the serum AMH levels are strongly related with the antral follicle count, this relationship is more significant than other ovarian reserve parameters. These results also indicate that the serum AMH measurement is a better predictor for the number of early antral follicles compared to conventional hormone measurements. Measuring AMH levels in combination with AFC may improve the assessment of ovarian reserve for evaluating fertility potential and monitoring infertility treatment. In the present study showed an inverse relationship between $25(\mathrm{OH}) \mathrm{D}$ and AMH among women ages 36-42, and no statistically significant correlation between $25(\mathrm{OH}) \mathrm{D}$ and $\mathrm{AMH}$ among women under the age of36. The prevalence of vitamin D deficiency was very high among the patients who participated in this study. However, no significant correlation was found between ovarian response with vitamin D and FSH levels.

\section{Acknowledgement}

My full thanks are presented to Dr. Salman Ali and my family and my close friends for their assistance and encouragement throughout this study.

\section{References}

Norman RJ, Dewailly D, Legro RS, Hickey TE. (2007). Polycystic ovary syndrome. Lancet, 370(9588): 685-97.

Qiao J. (2013). Pay more attention to ethnic differences in polycystic ovary syndrome phenotypic expression. Chin Med J (Engl), 126(11): 2003-6.

Goodarzi MO. (2011). Polycystic ovary syndrome: etiology, pathogenesis and diagnosis. Nat Rev Endocrinol, 7(4): 219-31.

Trikudanathan S. (2015). Polycystic ovarian syndrome. Med Clin N Am, 99(1): 22135.

Durlinger AL. (2001). Anti-Mullerian hormone attenuates the effects of FSH on follicle development in the mouse ovary Endocrinology, 142(11): 4891-9.

Grossman MP. (2008). Mullerian-inhibiting substance inhibits cytochrome P450 aromatase activity in human granulosa lutein cell culture. FertilSteril, 89(5): 1364-70.

Desforges-Bullet V. et al., 2010). Increased anti-mu" llerian hormone and decreased FSH levels in follicular fluid obtained in women with polycystic ovaries at the time of follicle puncture for in vitro fertilization. Fertil Steril, 94(1): 533 198-204.

Catteau-Jonard S, Dewailly D. (2013). Pathophysiology of polycystic ovary syndrome: the role of 
hyperandrogenism. Front Horm Res, 40, $22-7$.

Bouillon R. (2015). Vitamin D: from photosynthesis, metabolism, and action to clinical applications, endocrinology: adult and pediatric: vitamin $\mathrm{D}, 7$ th ed. Philadephia, PA: Elsevier, 7, 1018-37.

Irani M, Merhi Z. (2014). Role of vitamin D in ovarian physiology and its implication in reproduction: a systemic review. FertilSteril, 102:460-8.

Parikh G, Varadinova M, Suwandhi P, Araki T, Rosenwaks Z, Poretsky L, SetoYoung D. (2010). Vitamin D regulates steroidogenesis and insulin-like growth factor binding protein-1 (IGFBP-1) production in human ovarian cells. Horm Metab Res, 42:754-7.

Molly PJ, Peng L, Wang J, Feldman D. (2009). Interaction of the vitamin D receptor with a vitamin $\mathrm{D}$ response element in the Mullerian-inhibiting substance (MIS) promoter: regulation of MIS expression by calcitriol in prostate cancer cells. Endocrinol., 150:1580-7.

Merhi Z, Doswell AD, Krebs K, Cipolla M. (2014). Vitamin D altersgenes involved in follicular development and steroidogenesisin human cumulus granulosa cells. J Clin Endocrinol Metab, 99: E1137-45.

FanchinR., Mendez Lozano D., Louafi N. (2005). Achour-Frydman N., Frydman R. Taieb J. Dynamics of serum antiMullerian hormone levels during theluteal phase of controlled ovarian hyperstimulation. Human Reproduction, 20,747-751.

Ficicioglu C., Kutlu T., Baglam E., Bakacak Z. (2006). Early follicular antimüllerian hormone as an indicator of ovarian reserve. Fertility and Sterility, 85(3): 592-596.

Van Rooij I.A., Broekmans F.J., TeVelde E.R., Fauser B.C., Bancsi L.F., De Jong F.H. and Themmen A.P. (2002). Serum
anti-Mullerian hormone levels: a novel measure of ovarian reserve. Human Reproduction, 17, 3065-3071.

Tietz N.W. (1995). Clinical guide to laboratory tests. W. B Saunders, Philadelphia. 3rd Ed, 216-217.

Grossman M, Nakajima S, Fallat M, Siow Y. (2008). Müllerian inhibiting substance inhibits cytochromeP450 aromatase activity in human granulosa lutein cell culture. Fertil. Steril, 89: 1364-1370.

Schriock E, Li L, Dougall K, Givens C. (2012). Prevalence and Risk Factors of Vitamin D Deficiency in Women with Infertility Fertility and sterility; 97(3).

Ozkan S, Jindal S, Greenseid K. (2010). Replete vitamin D stores predict reproductive success following in vitro fertilization. Fertil Steril. 94(4):13141319.

Anifandis GM, Dafopoulos K, Messini CI, Chalvatzas N, Liakos N, Pournaras S. (2010). Reprod Biol Endocrinol. 28; 8: 91-95.

Johnson LE, DeLuca HF. (2002). Reproductive defects are corrected in vitamin d-deficient female rats fed a high calcium, phosphorus and lactose diet. J Nutr. 132(8): 2270-2273.

Van Rooij A.J., Frank J.M., Gabrielle J., Caspar W. N., Bart J.M., Axel P. N. (2005). Serum anti-mullerian hormone levels best reflect the reproductive decline with age in normal women with proven fertility: a longitudinal study. American Society for Reproductive Medicine, 83, 4.

Steingrimsdottir L, Gunnarsson O, Indridason OS, Franzson L, Sigurdsson G. (2005). Relationship between serum parathyroid hormone levels, vitamin D sufficiency, and calcium intake. JAMA. 294: 233641.

Baradaran A, Behradmanesh S, Nasri H.(2012). Association of body mass index and serum vitamin $\mathrm{D}$ level in 
healthy Iranian adolescents. Endokrynol Pol, 63: 29-33.

Bischoff-Ferrari H, Borchers M, Gudat F, Dürmüller U, Stähelin H, Dick W.(2004). Vitamin D receptor expression in human muscle tissue decreases with age. J Bone Miner Res. 19: 265-9.

Holick MF. (2007). Vitamin D deficiency. N Engl J Med, 357: 266-281.

Merhi Z, Doswell AD, Krebs K, Cipolla MJ. (2014). Vitamin D alters genes involved in follicular development and steroidogenesis in human cumulus granulosa cells. J Clin Endocrinol
Metab, 14: jc20134161.

Nakamura K, Nashimoto M, Matsuyama S, Yamamoto M. (2014). Low serum concentrations of 25-hydroxyvitamin D in young adult Japanese women: a cross sectional study. Nutrition, 17: 921-925.

Ross, L., Ingles, S., Rudick, B., Stanczyk, F., Ma, L., Chung, K. and Bendikson, K. (2014). Correlation of Serum Antimullerian Hormone with Vitamin D Levels in Women Undergoing IVF and Egg Donation. Fertility and Sterility, 101(2), e24-e25.

\section{How to cite this article:}

Hiba H. Kadhim and Salman A. Ahmed. 2019. The Associations of Serum AMH, Vitamin D, FSH and AFC in Different Age Groups of Infertile Women. Int.J.Curr.Microbiol.App.Sci. 8(01): 954-962. doi: https://doi.org/10.20546/ijcmas.2019.801.104 